\title{
Arms Control in Crisis: An Assessment of Contemporary Trends Sufian Ullah*
}

\begin{abstract}
Arms control regime has witnessed severe setbacks in recent years. This paper addresses the question that despite acknowledged benefits of arms control for peace and stability, the major powers are currently turning against arms control. By analyzing the reasons behind ongoing arms control crisis, the paper takes into account contending perspectives of major powers to map the emerging trends in arms control. The mere existence of nuclear weapons does not encourage the states to adopt restraint measures, rather it is their perception about the risks and challenges to their security that compel them to go for arms control. The ongoing geo-political competition, also exhibited in the form of strategic rivalries at global level, and advanced military-technological developments sans any consensus on mutual vulnerabilities shape the understanding of nuclear armed states for strategic stability. These are the two primary drivers behind the evolving arms control crisis. Recently, United States has veered away from its bilateral commitments that signifies the collapse of arms control arrangements between Washington and Moscow which originally served as a stabilizing factor in their adversarial relations. Prevailing disagreements on the constituents of strategic stability, concerns about other state's compliance and transparency, and accentuating differences in military capabilities are the defining features of how major states currently pursue arms control. In the absence of consensus on what threatens strategic stability among adversaries, any prospects for new arms control measures remain bleak. This factor also diminishes the prospects of any trilateral arms control agreement among U.S., Russia and China.
\end{abstract}

Keywords: Arms control, collapse, bilateral commitments, strategic stability, consensus

\footnotetext{
* The author is a Visiting Faculty at the Department of International Relations, National University of Modern Languages (NUML), Islamabad. He can be contacted at: sufianullah@numl.edu.pk:
}

@ 2020 by the Islamabad Policy Research Institute.

IPRI Journal — XX (2): 118-147.

https://doi.org/10.31945/iprij.200205. 


\section{Sufian Ullah}

\section{Introduction}

7 he arms control regime has confronted serious setbacks in the recent years. The existing arms control arrangements are already collapsing and there seems no prospects for any future restraint measures because of increasing political polarization, growing differences on the understanding of mutual stability and uncertainty around how new technologies may affect the future of warfare and strategic stability between the states that compete for technological supremacy. These trends signify an arms control crisis in which growing pessimism towards restraint measures may eventually lead to gradual erosion of the Cold War arms control arrangements, with significant implications for the existing multilateral arms control regime. The demise of Intermediate Range Nuclear Forces (INF) and the uncertainty surrounding the fate of New Strategic Arms Reduction Treaty (New START) are the most vivid expressions of this crisis. The increasing political alienation at the systemic level - where United States considers the other two major powers i.e. China and Russia as revisionist states - and ongoing competition in new military technologies hint at the beginning of new arms race with severe implications for global peace and security.

This research paper is an attempt to understand differing approaches of major powers towards arms control. By taking into account different perspectives of competing states, it argues that arms control is a product of risky environment and states adopt restraint measures only when they perceive mutual vulnerability. The current U.S. strategic behavior is poised towards retaining strategic supremacy at the nuclear level over both Russia and China. ${ }^{1}$ Washington's blatant disregard towards the notion of mutual

1 The following studies allude to U.S. aspirations to ensure technological and military supremacy. For details, see Barbara Lippert and Volker Perthes, eds., "Strategic Rivalry between United States and China: Causes, Trajectories, and Implications for Europe," (paper, Stiftung Wissenschaft und Politik, German Institute for International and Security Affairs, Berlin, 2020), doi:10.18449/2020RP04; Ashley J. Tellis, Alison Szalwinski, and Michael Wills, eds., U.S.-China Competition for Global Influence: The Return of U.S.-China Global Strategic Partnership (National Bureau of Asian Research, 2020); and Marianne Schneider-Petsinger, Jue Wang, Yu Jie and James Crabtree, "US- 
assured destruction is a defining character behind its lack of serious interest in restraint measures. This is evident from the increasing role of nuclear weapons to deter both nuclear and non-nuclear threats. The NonProliferation Review 2018, observes that "U.S. nuclear forces [are] increasingly flexible to tailor deterrence strategies across a range of potential adversaries and threats, and enable adjustments over time. Accordingly, the United States will maintain the range of flexible capabilities."

In the environment of heightened tensions and growing risks, can arms control help states to minimize the security dilemma and avoid military competition? The paper argues that this approach adds to stability only if the contesting players are willing to diffuse their tensions and use arms control as a tool for 'détente and conflict regulation.' Unless there is a consensus on the risks that prevailing strategic environment and emerging trends pose to global security, any prospects for future arms control measures seem very bleak. As states seek to amass maximum technological capabilities to deny adversary of any decisive advantage, they show reluctance to see arms control as a viable strategy to enhance security. It appears that the major actors intend to buy maximum possible time to develop enough capabilities and see how new technologies impact the strategic stability before fully agreeing to put limits to numbers and types of their capabilities.

To understand the ongoing global arms control crisis, the paper offers conceptual explanation of why do states remain engaged in arms competition and identifies the opposing perspectives and strategic objectives of competing states. The paper also delves on the recent U.S. proposal of engaging China into trilateral arms control negotiations. It identifies that China's limited nuclear arsenal and its strategic thinking that

China Strategic Competition: The Quest for Global Technological Leadership,” (paper, Chatham House: The Royal Institute of International Affairs, 2019), https://www.chathamhouse.org/sites/default/files/publications/research/CHHJ7480-USChina-Competition-RP-WEB.pdf.

${ }^{2}$ U.S. Department of Defense, Nuclear Posture Review 2018 (Washington, D.C.: US Department of Defense, 2018), https://media.defense.gov/2018/Feb/02/2001872886/-1/1/1/2018-NUCLEAR-POSTURE-REVIEW-FINAL-REPORT.PDF. 


\section{Sufian Ullah}

eschews nuclear first use and conversely relies more on retaliatory capability of its nuclear forces provide little incentive for Beijing to engage in negotiations with other two nuclear armed states that possess most of the nuclear weapons in the world.

\section{Why Arms Control Withers?}

Despite significant benefits offered by the arms control to enhance mutual security, why do states often show reluctance to pursue it as a viable policy approach? The ongoing arms control crisis indicates that states generally hesitate to bind themselves in legally binding restraint measures affecting their strategic choices. Even after reaching an agreement, as the opponents of arms control approach would argue, states can never be sure of each other's intentions and their sincere compliance to the agreement. Irving Kristol argued that the arms control agreements would always have limited scope and remain vulnerable to technological innovations in weapons systems thus leading to conflicting interpretations. ${ }^{3}$ Though the views of arms control proponents prevailed during the Cold War, the assessments by skeptics have proven relevant lately, as evident from ongoing arms control crisis between the U.S. and Russia. Limited transparency and lack of information about adversary's capabilities generate mistrust regarding other party's compliance to any agreement.

The INF Treaty, signed by US and the former Soviet Union in 1987, was to prohibit the development of land-based delivery systems with a range of 500 to 5500 kilometers, ${ }^{4}$ has become a victim of this dilemma. In the past few years, both U.S. and Russia have accused each other of violating the INF Treaty. In July 2014, US concluded that Russia had been violating the Treaty by testing the prohibited ground-launched cruise

\footnotetext{
3 Joseph S. Nye Jr, “Arms Control and International Politics," Daedalus 120, No. 1 (Winter 1991): 145-166 (147).

${ }^{4}$ Gotz Neuneck, "The Deep Crisis of Nuclear Arms Control and Disarmament: The Stateof Play and the Challenges," Journal for Peace and Nuclear Disarmament, Vol. 2, No. 2 (2019): 431-452 (434), https://doi.org/10.1080/25751654.2019.1701796.
} 
Arms Control in Crisis: An Assessment of Contemporary Trends

missile. ${ }^{5}$ In May 2016, Russia accused that the U.S. development of MK41 launch system under Aegis missile defence shield constituted the violation of INF Treaty. ${ }^{6}$ US decided to walk away from the Treaty in August 2019, citing that Moscow's non-compliance posed direct threats to the US and its allies. ${ }^{7}$ The other examples of failing agreements include Anti-Ballistic Missle Treaty, Open Skies Treaty, and the questionable future of New START. Similarly, US has repeatedly accused both China and Russia of lack of transparency on their nuclear programs.

To address the stated issues of non-compliance and opaqueness, Trump Administration thus proposed the multilateral arms control arrangement. ${ }^{8}$ Likewise, the rapid technological advancements, such as precision strike capabilities, and their possible integration with artificial intelligence enabled systems which have made states more skeptical about each other's intentions and possible strategic implications of these systems, thus further dampening the prospects of new arms control measures. These factors signify that Prisoner's Dilemma remains at play even after an arms control agreement becomes effective. It may also generate 'mixed-motive games, as specified by Kenneth Abbott, in which a state may feel the incentive to cooperate but at the same time it feels the conflicting incentive to breach or withdraw from an agreement and adopt an independent course of action..$^{9}$ In such a dilemma, a state feels relative advantage in defecting from a cooperative mechanism to minimize the payoffs of the other party. ${ }^{10}$

${ }^{5}$ Michael R. Gordon, “U.S. Says Russia Tested Cruise Missile, Violating Treaty,” New York Times, July 28, 2014, https://www.nytimes.com/2014/07/29/world/europe/us-saysrussia- tested-cruise-missile-in-violation-of-treaty.html.

6 "Russia says US Missile System Breaches Nuclear INF Treaty," BBC News, May 11 2019, https://www.bbc.com/news/world-europe-36269734.

${ }^{7}$ U.S. Department of State, "U.S. Withdrawal from the INF Treaty on August 2, 2019," press release, August 2, 2019, https://www.state.gov/u-s-withdrawal-from-the-inftreaty-on-august-2-2019/.

${ }^{8}$ Ibid. The Press Statement by the U.S. Department of State notes that the Trump Administration would begin "a new era of arms control that moves beyond the bilateral treaties of the past".

9 Kenneth W. Abbott "Trust But Verify: The Production of Information in Arms Control Treaties and Other International Agreements," Cornell International Law Journal 26, No.1 (1993):1-58 (3), https://scholarship.law.cornell.edu/cilj/vol26/iss1/1/.

${ }^{10}$ Ibid., 5. 


\section{Sufian Ullah}

The mere possession of nuclear weapons threatens the adversaries from engaging into any all-out conflict. However, there is always an unending arms competition between nuclear rivals in which a state is either developing disarming first-strike capabilities or striving to ensure nuclear survivability by developing more credible retaliatory forces. ${ }^{11}$ This represents a formal model of arms race in which each side builds arms in a strategic situation to deter the other and simultaneously believes that the other is engaged in seeking arms superiority over it, thus leading to huge weapons stocks on both sides. ${ }^{12}$ Even the defensive states may see the acquisition of more weapons as a mean to achieve two-pronged objectives that include: reinforcing deterrence by creating the fear of more destructive war and providing insurance against technological innovations that may undermine the effectiveness of its own weapons..$^{13}$

The Chinese approach of responding to military technological innovations holds relevance to both of these assertions. The U.S. continues to develop ballistic missile defence systems and counterforce weapons including Conventional Prompt Global Strike (CPGS) capabilities - that could eliminate Beijing's ability to carry out retaliatory strike. ${ }^{14}$ Chinese thinkers believe that such capabilities may lull U.S. towards preemptive tendency, thus requires Beijing to adjust its force posture. They also assert that this growing conventional threat to nuclear survivability necessitates the development of missile defence systems ${ }^{15}$ and puts strain on Beijing's

\footnotetext{
${ }^{11}$ For details, see Keir A. Lieber and Daryl G. Press, "The New Era of Counterforce: Technological Change and the Future of Nuclear Deterrence," International Security 41, No. 4 (Spring 2017): 9-49 (10).

${ }^{12}$ Michael D. Intriligator and Dagobert L. Brito, “Arms Race and Instability," Journal of Strategic Studies 9, No.4 (1986): 113-131 (113).

${ }^{13}$ Ibid., 114.

${ }^{14}$ Fiona S. Cunningham and M. Taylor Fravel, "Assuring Assured Retaliation: China's Nuclear Posture and U.S.-China Strategic Stability," International Security, Vol. 40, No. 2 (Fall 2015): 7-50 (8), https://doi.org/10.1162/ISEC_a_00215.

${ }^{15}$ See, Tong Zhao, "Conventional Challenges to Strategic Stability: Chinese Perception of Hypersonic Technology and the Security Dilemma," (paper, Carnegie-Tsinghua Center for Global Policy, 2018, 13.
} 
rationale of extending unconditional NFU commitment. ${ }^{16}$ Further, China has traditionally maintained the policy of 'not falling behind' in the domain of technological developments in order to avoid any technological surprise. ${ }^{17}$ This signifies that the qualitative and quantitative enhancement of weapons keeps the rival states engaged in an interactive arms acquisitions contributing to an unending arms race.

Before the nuclear revolution, wars could be seen as a zero-sum game where states competed for military victories. However, the theory of nuclear revolution propagated that the war dynamics were now altered as the nuclear rivals, despite their relative military strengths, had the ability to destruct each other thus making wars less likely to occur. The notion of Mutually Assured Destruction (MAD), based on assured retaliatory capabilities of adversaries, has been seen as a guarantee to deny any incentives to launch disarming pre-emptive strike. Keir A. Lieber and Daryl G. Press contest this notion and argue that the nuclear stalemate can be broken because of rapid technological advancements that have made states wary of their vulnerability against possible counterforce attacks. This dilemma consequently undermines the logic of MAD and fuels strategic competition and arms race. This assertion also suggests that as new weapons related technologies continue to evolve, the mutual mistrust and strategic competition would only intensify. As the nuclear rivals have seemingly failed to find an alternative to deterrence for a stable relationship, one may predict that the notion of deterrence would continue to remain relevant in the foreseeable future. Nevertheless, it requires a review of challenges confronting this base-line concept and also eschewing the doctrines that may undermine this notion. However, little progress is seen in this context.

Absence of concrete mechanisms for strategic negotiations between antagonistic powers signifies arms race instability - a situation in which states engaged in arms race continue to advance their capabilities to

\footnotetext{
${ }^{16}$ Yao Yunzhu, "China Will Not Change its Nuclear Policy," China-U.S. Focus, April 22, 2013,https://www.google.com/search?client=safari\&rls=en\&q=Yunzhu+Yao,+\%22Chin $\mathrm{a}+$ Will+Not+Change+Its+Nuclear+Policy, $\% 22 \& \mathrm{ie}=\mathrm{UTF}-8 \& \mathrm{\& oe}=\mathrm{UTF}-8$.

${ }^{17}$ Zhao, "Conventional Challenges to Strategic Stability,"14.
} 


\section{Sufian Ullah}

higher levels without reaching an equilibrium. ${ }^{18}$ The apparent departure from MAD and pursuit of counterforce capabilities to undermine survivability of adversary's arsenal also exacerbate risks of crisis instability - a condition in which either state feels temptation or incentive to strike first to avoid the worse consequence of incurring a first strike. ${ }^{19}$ The counterforce options are not confined merely to nuclear capabilities and may also involve conventional capabilities. The blurring lines between conventional and nuclear forces allows an aggressor to hold adversary's second-strike forces at risk below the nuclear threshold. This not only complicates nuclear deterrence, as the use of nuclear weapons could become 'new normal' in such postures ${ }^{20}$ but also undermines the prospects of restraint and risk reduction measures.

While an arms race represents clash of competing interests of states having political differences, ${ }^{21}$ arms control signifies recognition of mutually shared concerns and threats to each other's national security. The arms control arrangements establish the status-quo as the two rivals agree on a de-facto military situation that enhances mutual security by discouraging aggression. ${ }^{22}$ This implies that arms control is a product of a risky environment and a state would agree to accept limitations on its sovereign choice to develop weapons only if it considers itself vulnerable to threats posed by the adversary. In an equation where a state perceives itself invulnerable to adversary's capabilities, the prospects of arms control

\footnotetext{
${ }^{18}$ Intriligator and Brito, “Arms Race and Instability," 113.

${ }^{19}$ Robert E. Linhard, "Crisis Stability in a Multipolar World," in Strategic Stability in the Post-Cold War World and the Future of Nuclear Disarmament, eds. Melvin L. Best Jr., John Hughes-Wilson, and Andrei A. Piontkowsky (Dordrecht: Springer, 1995), 85.

${ }^{20}$ Beyza Unal, Yasmin Afina and Patricia Lewis, eds., Perspectives on Nuclear Deterrence in the $21^{\text {st }}$ Century (Chatham House, 2020), 6 , https://www.chathamhouse.org/sites/default/files/2020-04-20-nuclear-deterrence-unalet-al.pdf.

${ }^{21}$ Andrew Kydd, "Arms Race and Arms Control: Modelling the Hawk Perspective," American Journal of Political Science, Vol.44, No.2 (2000): 228-244 (229), https://doi.org/10.2307/2669307.

${ }^{22}$ Tom Coppen, The Law of Arms Control and the International Non-Proliferation Regime: Preventing the Spread of Nuclear Weapons (Boston: Brill/ Nijhoff, 2016), 24.
} 
would remain low. During the Cold War, the two superpowers experienced a series of highly dangerous crises, such as the Cuban Missile crisis in 1962, which compelled the two leaderships to realize the intensity of dangers and take measures to avoid any catastrophe. ${ }^{23}$ When a relatively stronger power believes that it could gain enough military superiority to destroy the opponent, the arms control cannot become its high priority strategic objective.

\section{Retreat from Arms Control: A Crisis in the Making}

The bilateral arms control regime between US and Russia has witnessed severe setbacks in the post-Cold War world in which the global political order has gradually moved towards multipolarity. At a time when U.S. hegemony is declining, the renewed Sino-Russian relationship intensifies and asserts promotion of multipolarity as one of its foundational pillars. US believes that the revisionist ambitions of China and Russia aim to shape an international system based on authoritarian model. The geo-political tensions are also demonstrated in the form of a deteriorating arms control regime. After the withdrawal from ABM Treaty in 2002, the US has abandoned the INF Treaty, and the extension of New START is under question after it expires in 2021. Russia withdrew from the Treaty on Conventional Armed Forces in Europe (CFE) in 2015. The eroding bilateral arms control arrangements have a direct bearing on how major powers approach multilateral non-proliferation and disarmament related frameworks. US has withdrawn from the Joint Comprehensive Plan of Action (JCPOA). The incoming Joe Biden administration has promised to re-enter the nuclear deal, conditional to Iran's compliance, as part of its promised policy to recommit the US to multilateral agreements. ${ }^{24}$ However, any quick progress on this issue is unlikely because of apparent opposition

${ }^{23}$ Alexei Arbatov, An Unnoticed Crisis: The End of History of Nuclear Arms Control, report (Carnegie Endowment for International Peace, 2015), 5, http://www.jstor.org/stable/resrep12816.

${ }^{24}$ Ellie Geranmayeh, Barbara Slavin, and Sahil Shah, Renewing Transatlantic Strategy on Iran, report (Washington DC: Atlantic Council and European Leadership Network, 2020), 1 . 


\section{Sufian Ullah}

from Israel, Kingdom of Saudi Arabia and US domestic political opponents. ${ }^{25}$

There has been no progress in signatures and ratification of Comprehensive Test Ban Treaty (CTBT) by the remaining Annex-2 states, which further delays the Treaty's entry-into-force. Due to the disagreement over the inclusion of existing stockpiles of weapons-grade fissile material into the scope of the Treaty, the initiation of negotiations on the proposed Fissile Material Cut-off Treaty (FMCT) ${ }^{26}$ also remains uncertain. Likewise, states are following a path from space militarization to weaponization. ${ }^{27}$ The negotiation process on the Prevention of Arms Race in Outer Space (PAROS) in UN arms control bodies remain stalled, primarily due to major spacefaring nations continued to build offensive and defensive counter space capabilities. ${ }^{28}$ More recently, Trump administration decided to withdraw from the Open Skies Treaty, citing Russia's alleged noncompliance as a driving factor for this decision. ${ }^{29}$

Reports also suggest that senior officials within Trump administration considered the resumption of nuclear testing. ${ }^{30}$ From the technical aspect, nuclear testing is required to ensure the reliability of existing designs of nuclear weapons. US officials have already hinted at the possibility of resuming nuclear tests to ensure the credibility of warhead designs. US Secretary of Defence, Robert Gates, remarked in October 2008

\footnotetext{
${ }^{25}$ Ibid.

${ }^{26}$ Pakistan's official stance on FMCT is that the proposed Treaty must address the existing fissile material stockpiles possessed by the states. Pakistan proposes that the Treaty should be comprehensive and can be named as Fissile Material Treaty (FMT).

${ }^{27}$ Zulfqar Khan and Ahmad Khan, "Space Security Trilemma in South Asia," Astropolitics 17. No.1 (2019): 1-22.

${ }^{28}$ Ahmad Khan and Sufian Ullah, "Challenges to International Space Governance," in Handbook of Space Security, ed. KU Schrogl (Cham: Springer, 2020), 1-14.

${ }^{29}$ Kingston Reiff and Shannon Bugos, "U.S. to Withdraw from Open Skies Treaty," Arms Control Association, June 2020, https://www.armscontrol.org/act/2020-06/news/uswithdraw-open-skies-treaty.

${ }^{30}$ Or Rabinowitz and James Cameron, "Trump Officials Have Talked about Resuming Nuclear Testing. Here's Why that Would Hurt the U.S.," Washington Post, May 30, 2020, https://www.washingtonpost.com/politics/2020/05/30/trump-officials-havetalked-about-resuming-nuclear-testing-heres-why-that-would-hurt-us/.
} 


\section{Arms Control in Crisis: An Assessment of Contemporary Trends}

that,"there is absolutely no way we can maintain a credible deterrent and reduce the number of weapons in our stockpile without either resorting to testing our stockpile or pursuing a modernization program." 31 Another technological motivation behind possible nuclear testing can be to diversify the US nuclear stockpiles. Since non-testing allows a nuclear-armed state to keep only a fewer types of weapons, resumption of testing would allow the US to ensure the reliability of existing warheads.

US has also expressed concerns about Russia and China's noncompliance to commitment to not test nuclear devices. ${ }^{32}$ It recently accused China of maintaining high level of activity at its Lop Nor test site. ${ }^{33}$ The official US estimates note that Chinese nuclear arsenal is likely to double in the next decade in its drive to achieve nuclear parity with US. ${ }^{34}$ Likewise, it has accused Russia of conducting low-yield nuclear tests. ${ }^{35}$ Russia reportedly maintains 1850 non-strategic nuclear weapons (NSNWs), as compared to US 500 NSNWs. ${ }^{36}$ There is a growing belief in Washington that Russian low-yield NSNWs offer Moscow's greater flexibility and options to actually use nuclear weapons against the US and its allies that

\footnotetext{
${ }^{31}$ National Institute for Public Policy, The Comprehensive Test Ban Treaty: An Assessment of the Benefits, Costs, and Risks (Fairfax, VA: National Institute Press, 2011), 24-25, http://www.nipp.org/wp-content/uploads/2014/12/CTBT-3.11.11electronic-version.pdf.

${ }^{32}$ For further reference, see Bureau of Arms Control, Verification and Compliance, Adherence to and Compliance with Arms Control, Non-Proliferation, and Disarmament Agreements and Commitments (Compliance Report), report (Washington DC: The U.S. Department of Defense, June 2020).

${ }^{33}$ Michael R. Gordon, "Possible Chinese Nuclear Testing Stirs U.S. Concern," Wall Street Journal, April 15, 2020, https://www.wsj.com/articles/possible-chinese-nuclear-testingstirs-u-s-concern-11586970435.

${ }^{34}$ U.S. Office of the Secretary of Defense, Military and Security Developments Involving People's Republic of China, report (Washington DC: U.S. Office of the Secretary of Defense, 2020), 85.

35 Daryl G. Kimball, “U.S. Questions Russian CTBT Compliance,” Arms Control Association, July/August 2019, https://www.armscontrol.org/act/2019-07/news/usquestions-russian-ctbt-compliance.

${ }^{36}$ Daryl Kimball and Kingston Reif, "The Presidential Nuclear Initiatives (PNIs) on Tactical Nuclear Weapons at a Glance,” Arms Control Association, July 2017, https://www.armscontrol.org/factsheets/pniglance.
} 


\section{Sufian Ullah}

undermines the credibility of its deterrence. Thus, resumption of nuclear testing may serve as a tool to bolster its deterrence against Russia and China. It not only undermines the credibility of CTBTO's International Monitoring System based verification regime but also triggers debate around US compliance and possible withdrawal from this multilateral arrangement. This trend signifies a looming threat where undermining the taboo on nuclear testing may consequently encourage the US to exhibit willingness to actually use nuclear weapons capability in future crises. Nuclear taboo serves only as a normative basis of nuclear restraint. ${ }^{37}$ If a country exhibits willingness to break the taboo on nuclear testing, there is lesser probability that it would be hesitant to break the taboo on the use of nuclear weapons, particularly in a strategic environment where the threshold of nuclear use is low and use of nuclear weapons may become a 'new normal. ${ }^{38}$

The US and Russia agreed to a set of arms control agreements like Strategic Arms Reduction Treaty (START), Strategic Offensive Reductions Treaty (SORT) and New START with an aim to regulate destabilizing nuclear arms competition, reduce the risk of inadvertent escalation, and to ensure the strategic balance. These agreements aimed to reduce the number of warheads on both sides and were framed around a common understanding to minimize incentives on either side to carry out preemptive first strikes. ${ }^{39}$ This understanding was a product of mutual recognition of each other's vulnerabilities against their assured retaliatory capabilities and reciprocal fear of surprise attack. It helped them explore the means to avoid aggression and bolster crisis stability. The end of Cold War and reducing fear of nuclear confrontation as its consequence implicated the mutually felt need to regulate arms race and enact new arms

\footnotetext{
${ }^{37}$ Gerald C. Brown, "Deterrence, Norms, and the Uncomfortable Realities of a New Nuclear Age," War on the Rocks, April 20, 2020, 
control arrangements. ${ }^{40}$ This significant departure from mutual belief in strategic stability has thus severely implicated existing arms control structures and puts strain on the global peace and security. Not restricted by limitations previously imposed by INF Treaty, US officials have expressed readiness to deploy intermediate-range ballistic missiles in Asia-Pacific and Europe ${ }^{41}$ Though it remains to be seen if Washington's allies in the region are willing and able to host the US inter-mediate range missiles, this decision draws strong opposition from Russia and China. The Chinese Ministry of National Defence warned that it would not sit idly and take countermeasures against the possible deployment of land-based medium range missiles in Asia-Pacific countries. ${ }^{42}$

\section{Driving Factors behind Arms Control Crisis}

There are two primary factors that contribute to ongoing crisis in arms control. First, differing perceptions among competing states about what really constitutes stability between them and, secondly, how new military technology threatens strategic stability. On political front, the US views China and Russia as revisionist powers that "want to shape a world consistent with their authoritarian model." 43 There is a renewed competition between Washington and Moscow whereby, the former sees the latter as a 'revitalized malign actor' seeking to undermine the U.S. global

\footnotetext{
${ }^{40}$ Eugene Rumer, “A Farewell to Arms... Control," Carnegie Endowment for International Peace, April 17, 2018, 1. Alexei Arbatov also share the similar assessment and argues that the transition from competition to cooperation between U.S and Russia eliminated the threat of nuclear war and thus implicated the importance of arms control. For details, see Arabtov, An Unnoticed Crisis, 6.

41 "US Deploying Intermediate-Range Missiles in Asia Pacific Not Easy," China Military Online, June 18, 2020, http://eng.chinamil.com.cn/view/2020-06/18/content_9837662 .htm.

42 Ibid.

${ }^{43}$ U.S. Department of Defence, Summary of the National Defence Strategy of the United States of America: Sharpening the American Military's Competitive Edge (U.S. Department of Defence, 2018), 2, https://dod.defense.gov/Portals/1/Documents/pubs/2018-National-Defense-StrategySummary.pdf.
} 


\section{Sufian Ullah}

leadership. ${ }^{44}$ The growing geo-political tensions lead to strategic rivalries, as demonstrated in the form of competing military modernization programs. These conditions have led arms control into a crisis where states are relatively pessimistic towards engaging in strategic negotiations and pursue restraint measures. Likewise, the economic and military rise of China also influences the US approach towards arms control and should be seen as a part of Washington's broader political-military strategy towards adversarial states.

Development of new technologies that can have significant impact on nuclear stability is also impacting the strategic environment. It has a potential to alter the nature and character of the warfare. The disruptive technologies are the ones that displace an established technology and provide its possessor a decisive advantage over the others. Few examples of such technologies include innovations in Lethal Autonomous Weapons Systems (LAWS), robotics, Hyper Glide Vehicles (HGVs), unattended ground sensors, unmanned aerial and underwater vehicles, cyber, space, fire-and-forget missiles and so on. The major concern with new technologies is that despite being conventional in nature, their possible employment in military operations may yield strategic implications. The increasingly blurring lines between the conventional and nuclear weapons would heighten uncertainty among adversaries and thus complicate deterrence. With the rapid development of these technologies, the adversarial states will have to be prepared for 'grey zone' operations ${ }^{45}$ whereby, these conventional tools may undermine other states' command and control systems and retaliatory capabilities. This looming threat to nuclear deterrence may compel the nuclear armed states to exhibit intent to use nuclear weapons to deter non-nuclear attacks. Since these technologies are likely to operate in tandem with each other, hence the impact is

\footnotetext{
44 The Department of Defence, Indo-Pacific Strategy Report: Preparedness, Partnerships, and Promoting a Networked Region, report (Department of Defence, 2019, 11, https://media.defense.gov/2019/Jul/01/2002152311/-1/-1/1/DEPARTMENT-OFDEFENSE-INDO-PACIFIC-STRATEGY-REPORT-2019.PDF.

${ }^{45}$ Unal, Perspectives on Nuclear Deterrence in the $21^{\text {st }}$ Century, 7.
} 
Arms Control in Crisis: An Assessment of Contemporary Trends

amplified considerably. ${ }^{46}$ Along with the urge to dominate technological development in these domains, uncertainty surrounding the strategic implications of new technologies and how these may impact the strategic balance among rival states explain why states are turning against the arms control and are unwilling to consider the new legally binding instruments.

While many states are willing to negotiate a legally binding instrument on systems like LAWS, major powers seem to avoid negotiations on legally binding mechanisms or code of conduct on the employment of these weapons. For instance, the member states of NonAligned Movement (NAM) call for a legally binding instrument on prohibitions and regulations on LAWS. ${ }^{47}$ NAM members even urge all the states to declare moratoria on further development and use of LAWS. ${ }^{48}$ Some other countries like France and Germany do not show much interest in legally binding instrument and rather emphasize on their "support for exploring a political declaration." 49 The US, on the other hand, stresses on not to set new international standards and "stigmatize new technologies," and only call for responsible use of weapons. These somehow contradictory positions signify that while states point on different approaches to regulate emerging technologies, the prospects of arms control on evolving weapons related technologies are marred by the difference on mutual understanding of how these systems implicate their securities. This is also evident from continued unchecked technological developments that consequently shape

\footnotetext{
${ }^{46}$ Ibid., 30.

47 Jorge Valero, "Group of Governmental Experts of the High Contracting Parties to the Convention on the Prohibitions or Restrictions on the Use of Certain Conventional Weapons which may be deemed to be Excessively Injurious or to have Indiscriminate Effects," (speech, United Nations Office, Geneva August 29, 2018), 2, http://reachingcriticalwill.org/images/documents/Disarmament-fora/ccw/2018/ gge/statements/29August_NAM.pdf.

${ }^{48}$ Ibid., 3.

${ }^{49}$ Reaching Critical Will, "Possible Options for Addressing the Humanitarian and International Security Challenges, GGE on LAWS, 29 August 2018”, accessed on January 29, 2020, http://reachingcriticalwill.org/images/documents/ Disarmamentfora/ ccw/2018/gge/statements/29August_France_Germany.pdf.
} 


\section{Sufian Ullah}

major powers' choice to place arms control on backburner in a bid to gain a competitive strategic advantage over each other.

Unilateralism and preferring strategic dominance over strategic stability ignites the security dilemma and undermines arms race stability. While the emerging technologies continue to cause friction among technologically advanced countries, the weapons related technological advancements - with no multilateral checks in place - lead to uncertain environments. This is more worrisome in a scenario of possible integration of artificial intelligence with hypersonic vehicles and other nuclear capable delivery systems. The world is also witnessing fast progress in technologies like ballistic missile defence systems, high-precision conventional weapons that chase their targets at hypersonic speed and greater accuracy, and other sophisticated technologies including cyber and artificial intelligence. Considering the significant strategic implications of these technologies on nuclear deterrence and future of warfare, the major powers are determined not to fall behind in this technological competition. It is worth recalling President Putin's statement that whoever leads in artificial intelligence will lead the world..$^{50}$

To deny each other of achieving a monopolistic position in technological domain, the competing states are reluctant to enter into or even continue adhering to arms control agreements. This scenario is a precursor of an unpredictable situation with increased pace of crisis and fail-deadly situations, leading to a nuclear war. The integration of artificial intelligence in decision making processes and implementation of those decisions is particularly worrisome in this regard. The uninhabited nuclear launch platforms would pose challenge for positive human control over nuclear weapons and fail-safe measures. ${ }^{51}$ Reports suggest that at least two nuclear armed states are considering the possibility to use unmanned

\footnotetext{
50 "Putin: Leader in artificial intelligence will rule world," $C N B C$, September 4, 2017, https://www.cnbc.com/2017/09/04/putin-leader-in-artificial-intelligence-will-ruleworld.html.

${ }^{51}$ Michael C. Horowitz, Paul Scharre, and Alexander Velez-Green, “A Table Nuclear Future? The Impact of Automation, Autonomy, and Artificial Intelligence" (paper, University of Pennsylvania, 2017), 22.
} 
vehicles for nuclear delivery. These include Russia's nuclear capable unmanned underwater vehicle (UUV) Poseidon and American nuclear capable optionally manned B-21 Raider. ${ }^{52}$

The rapid advancements in intelligence and surveillance capabilities, in addition to high-precision strike delivery systems, now enable the conventional weapons to destroy adversary's nuclear forces. The submergible unmanned drones and satellites with advanced sensors can now severely undermine adversary's nuclear survivability by detecting road-mobile nuclear delivery systems and nuclear ballistic missile submarines (SSBNs), which are otherwise seen as potent weapons for assured second-strike capability. The ability to ensure survivability of SSBNs may vary on the basis of technologies employed by different states and the US dominates its counterparts in this domain. ${ }^{53}$ Exploring conventional alternatives to nuclear strike options blurs the lines between nuclear and conventional warfare and thus directly leads to crisis instability. In this competition for technological dominance, the aggravated security dilemma not only reduces the incentives to consider arms control as a viable strategic option, but also increases states' reliance on nuclear weapons in a possible conflict situation. The conventional emerging technologies offer options for large-scale offensive operations and there seem little prospects to restrict the new systems. The states developing such capabilities hesitate to enter into negotiations to control these capabilities. The US National Strategy for Critical and Emerging Technologies, released in October 2020, calls to lead innovation in science and technology by prioritizing emerging technologies for national security. ${ }^{54}$

\footnotetext{
${ }^{52}$ Vincent Boulanin, ed., The Impact of Artificial Intelligence on Strategic Stability and Nuclear Risk (Stockholm International Peace Research Institute, 2019), 57.

${ }^{53}$ Owen R. Cote Jr., "Invisible Nuclear-Armed Submarines, or Transparent Oceans? Are Ballistic Missile Submarines Still the Best Deterrent for the United States?" Bulletin of the Atomic Scientists 75, No. 1 (2019): 30-35 (30), https://doi.org/10.1080/00963402.2019.1555998.

${ }^{54}$ White House, National Strategy for Critical and Emerging Technologies (White House, October 2020), 1, https://www.whitehouse.gov/wp-content/uploads/2020/10/NationalStrategy-for-CET.pdf.
} 


\section{Sufian Ullah}

Given these trends, the contesting major powers have different assessments of evolving trends and divergent approaches to pursue their strategic interests. These trends have direct implications for different regional levels, particularly South Asia, where India has ambitious pursuit of strategic superiority over Pakistan and its escalation dominance strategies undermine the prospects of arms control. The section below offers an assessment of these approaches to conclude how perceived vulnerabilities and lack of consensus among competing states diminish the prospects of a strengthened arms control regime.

\section{An Assessment of U.S. Approach towards Arms Control}

The US position on the recent situation of arms control regime is driven by the changing perceptions about strategic stability. The classical concept of strategic stability, as defined by Robert Oppenheimer, implied to a situation in which the two sides are capable of destroying each other, but only at the risk of its own survival. ${ }^{55}$ In such a situation, no party has an incentive to use nuclear weapons and adopt a stabilizing posture that "should both be demonstrably survivable and exhibit restraint." ${ }^{56}$ The current US perspective maintains that the threats to strategic stability no longer confine merely to rivalry between two super powers at the global level, rather these are shaped by the changing nature of interstate competition at different regional levels - as manifested by "Russia's territorial aggrandizement in its near abroad, China's aggressive actions throughout its near seas, and Iran's efforts to extend its influence across its neighborhood." 57 The outgoing Trump administration had little optimism towards arms control and its decision to withdraw from several restraint measures only signified

\footnotetext{
${ }^{55}$ Wayne E. Lee, ed., Warfare and Culture in World History (New York: NYU Press, 2011), 193

${ }^{56}$ Elbridge A. Colby, "Defining Strategic Stability: Reconciling Stability and Deterrence," in Strategic Stability: Contending Interpretations, ed. Elbridge A. Colby and Michael S. Gerson (Strategic Studies Institute, US Army War College, 2013).

${ }^{57}$ Evan Braden Montgomery, "Source of Instability in the Second Nuclear Age: An American Perspective," in The End of Strategic Stability? Nuclear Weapons and the Challenge of Regional Rivalries, eds. Lawrence Rubin and Adam N. Stulberg (Washington DC: Georgetown University Press, 2018), 24.
} 
a weakening arms control regime that can be detrimental for arms control regime. The Nuclear Posture Review 2018, notes that "further progress [in arms control] is difficult to envision, however, in an environment that is characterized by continuing significant non-compliance with existing arms control obligations and commitments." 58

Hence, the American arms control approach is characterized by several points. First, the US accuses that Russia has been in violation of existing treaties that undermines its national security. ${ }^{59}$ Secondly, there is a belief that the traditional concept of strategic stability was relevant in a bipolar context and with the emergence of multipolar nuclear competitors, US has to optimize posture for its national security and that of its allies. ${ }^{60}$ Likewise, US also believes that Washington and Moscow should not alone take the restraint measures and global security requires that other nuclear powers, especially China, should also take responsibility and be included in multilateral negotiations for arms control. ${ }^{61}$

Thirdly, there have been voices within the US calling for acquiring nuclear dominance instead of just focusing on strategic stability. ${ }^{62}$ In recent years, the US seemingly pay little regard to strategic balance and mutual vulnerability as being the keys for maintaining strategic stability with its rivals. Contrarily, it emphasizes more on retaining an effective deterrence. This constitutes to the belief that maintaining superior military capability, instead of settling to the levels where mutual vulnerability is reinforced, may guarantee more security and contribute to strategic stability. This approach generates the impression in Russia and China that US no more

${ }^{58}$ U.S. Department of Defence, Nuclear Posture Review 2018, XVII.

${ }^{59}$ Nuclear Posture Review 2018 observes that "Russia continues to violate a series of arms control treaties and commitments, the most significant being the INF Treaty." For details, see ibid., 73.

${ }^{60}$ Montgomery, "Source of Instability in the Second Nuclear Age," 28.

61 "INF Nuclear Treaty: Trump Says New Pact Should Include China," BBC News, August 3, 2019, https://www.bbc.com/news/world-us-canada-49213892.

62 Mathew Kroenig, The Logic of American Nuclear Strategy: Why Strategic Superiority Matters (New York: Oxford University Press, 2018), quoted in Vince Manzo, Nuclear Arms Control without a Treaty? Risks and Options after New Start, (Center for Naval Analyses, 2019), 103, https://www.cna.org/CNA_files/PDF/IRM-2019-U-019494.pdf. 


\section{Sufian Ullah}

holds any regard for the concept of strategic stability ${ }^{63}$ Fourthly, with regards to pursuing nuclear disarmament, US seems to emphasize more on establishing new multilateral arrangements instead of doing progress on existing and already agreed upon measures. One such example is launching the initiative on Creating Environment for Nuclear Disarmament (CEND) which emphasizes that pursuit for nuclear disarmament cannot be timebound and requires addressing security issues that necessitate retaining nuclear weapons. ${ }^{64}$

The US claims that its military developments and deployments, like the global precision strike capabilities and ballistic missile defence systems, are a response to growing threats from Iran and DPRK, but China and Russia consider these weapons as significant threats to the survivability of their nuclear deterrent capabilities. ${ }^{65}$ By 2020 s, the US is likely to have a potent hyper glide vehicle force enabling it to evade adversary's antiaccess/area-denial capabilities and conduct targeted strike operations. ${ }^{66}$ Washington is developing 6,000 kilometer range boost glide-vehicle having the capability to target China from distant bases including Guam, Diego Garcia, and Royal Australian Airforce (RAAF) Base Tindal in Australia. ${ }^{67}$ Beijing believes that Washington may use its hypersonic technology development program and global prompt strike capabilities to pre-

${ }^{63}$ Amb (R) Aizaz Ahmad Chaudhry, Director General Institute for Strategic Studies Islamabad (ISSI), observed in his keynote address at the seminar titled "Strategic Stability in South Asia: Is India a Responsible Nuclear State?" that the experts of leading Chinese think tanks are concerned about growing disregard by the U.S. for the concept of strategic stability.

${ }^{64}$ Christopher Ashley Ford, "Moving Forward with the CEND Initiative" (speech, Creating an Environment for Nuclear Disarmament Working Group, Wilton Park, United Kingdom, November 20, 2019), https://www.state.gov/moving-forward-withthe-cend-initiative/.

${ }^{65}$ Gregory D. Koblentz, Strategic Stability in the Second Nuclear Age, report (Council on Foreign Relations, 2014), 21.

${ }^{66}$ Quoted in Heather Williams, "Asymmetric Arms Control and Strategic Stability: Scenarios for Limiting Hypersonic Glide Vehicles," Journal of Strategic Studies 42, No. 6 (2019): 789-813 (797), doi: 10.1080/01402390.2019.1627521.

${ }^{67}$ Shahryar Pasandideh, "The End of the INF Treaty and the US-China Military Balance," The Non-Proliferation Review 26, No.3-4 (2019): 1-21 (18), doi: 10.1080/10736700.2019.1646466. 
Arms Control in Crisis: An Assessment of Contemporary Trends

emptively strike Beijing's nuclear forces and its command and control system. ${ }^{68}$

Besides this risk of intentional counterforce strikes, there is also a threat of inadvertent escalation if Washington's conventional weapons target Beijing's dual-use military platforms. The US strategic thinkers recognize that any such possible use of conventional force may increase nuclear pressures on the opponents. ${ }^{69}$ The conventional weapons play a vital role in US' deterrent posture to discourage any aggression. ${ }^{70}$ However, this view is contested by the Chinese experts who believe that the conventional hypersonic weapons are not merely the weapons for deterrence, rather they may be used as war-fighting instruments. ${ }^{71}$ Nuclear Posture Review 2018 observes the Chinese anti-access and area-denial capabilities as a threat to its conventional precision strike weapons, ${ }^{72}$ and for a leading global power like US, it is imperative to retain superior edge in the development of these weapons. These aspects are the defining features of US approach towards arms control. Though incoming Biden administration promises recommitment to several arrangements, any major departure from the contemporary approach is unlikely. For instance, even if New START is extended further till 2026, it is unlikely to mark a turning point in US-Russia bilateral relations." 73 The underlying geopolitical and

${ }^{68}$ Tong Zhao, "Conventional Challenges to Strategic Stability: Chinese Perceptions of Hypersonic Technology and the Security Dilemma," in The End of Strategic Stability? Nuclear Weapons and the Challenge of Regional Rivalries, eds. Lawrence Rubin and Adam N. Stulberg (Washington DC: Georgetown University Press, 2018), 183.

${ }^{69}$ Caitlin Talmadge, "Would China Go Nuclear? Assessing the Risk of Chinese Nuclear Escalation in a Conventional War with the United States," International Security 41, No. 4 (Summer 2017): 50-92 (91), https://doi.org/10.1162/ISEC_a_00274.

${ }^{70}$ Nuclear Posture Review 2018 notes the nuclear forces, conventional forces and other instruments of national power are directed towards deterring aggression. For details, see U.S. Department of Defense, Nuclear Posture Review 2018, II.

${ }^{71}$ Zhao, "Conventional Challenges to Strategic Stability."

72 Ibid., 7.

${ }^{73}$ Andrey Baklitskiy, Will U.S. Election Herald the Return of Arms Control? (Moscow: Carnegie Moscow Center, 2020), https://carnegie.ru/commentary/83125. 


\section{Sufian Ullah}

strategic issues, as discussed above, would continue to shape incoming Biden administration's arms control agenda.

\section{An Assessment of Russian Approach towards Arms Control}

On the Russian side, the Putin administration's understanding of strategic stability revolves around the belief to have mutual deterrent relationship, based on strategic balance and parity, with the US. ${ }^{74}$ Russia believes that the US aspires to build unrestricted conventional and nuclear capabilities which requires Moscow to counterbalance and restore stability. After Washington withdrew from ABM Treaty in 2002, and started deploying its missile defence systems, Moscow objected that these systems would undermine its retaliatory capability ${ }^{75}$ The countermeasures involved the development of silo-based liquid-fuel inter-continental ballistic missile Sarmat and Avangard program to develop hypersonic glide vehicle. ${ }^{76}$ Sarmat has an estimated capability to carry up to 10 maneuverable warheads that make it an effective delivery system to evade adversary's missile defence systems. ${ }^{77}$ Moscow recently declared that it has operationalized its intercontinental range hypersonic missile. ${ }^{78}$

\footnotetext{
74 Andrey Pavlov and Anastasia Malygina, "The Russian Approach to Strategic Stability: Preserving a Classical Formula in a Turbulent World," in The End of Strategic Stability? Nuclear Weapons and the Challenge of Regional Rivalries eds. Lawrence Rubin and Adam N. Stulberg (Washington DC: Georgetown University Press, 2018), 62.

${ }^{75}$ Viktor Poznikhir, "US Layered Ballistic Missile Defence System: A Challenge to Russian and Chinese Security and Global Stability," (presented at the Conference on Disarmament, Geneva, March 28, 2017), quoted in Pavel Podvig, "Russia's Current Nuclear Modernization and Arms Control," Journal for Peace and Nuclear Disarmament 1, No.2 (2018): 256-267 (259), https://doi.org/10.1080/25751654.2018.1526629.

${ }^{76}$ Ibid., 260

${ }^{77}$ H. M. Kristensen and R. S. Norris," Russian Nuclear Forces, 2017," Bulletin of the Atomic Scientists 73, No.2 (2017): 115-126 (120), https://doi.org/10.1080/00963402.2017.1290375.

78 "Russia says its intercontinental hypersonic missile has entered combat duty," $C B C$, December 28, 2019, https://www.cbc.ca/news/world/russia-intercontinental-hypersonicweapon-1.5409419.
} 


\section{Arms Control in Crisis: An Assessment of Contemporary Trends}

While the Russian nuclear modernization effort may not necessarily involve the deployment of more nuclear weapons, it focuses on ensuring parity with the US to maintain mutually assured destruction and develop delivery systems that could ensure its credible retaliatory capability in the wake of American ballistic missile defence systems. ${ }^{79}$ Besides these weapons, Moscow's interest to build non-traditional strategic weapons not covered under any arms control agreements further add to complexity in US-Russia strategic rivalry. These include "naval, tactical air and missile defense forces, as well as on short-range ballistic missiles."

US believes that with the development of new delivery systems, Russia has adopted 'escalate to de-escalate' strategy where it may threaten to use lower-yield nuclear weapons in an attempt to dominate escalation ladder in a possible conflict with NATO ${ }^{81}$ Likewise, Russia feels concerned about growing US conventional capabilities, like prompt global strike and precision-strike cruise missiles. Russian thinkers believe that US may employ these conventional strategic weapons in a counterforce role to destroy Moscow's command and control and nuclear retaliatory capability ${ }^{82}$ Russia seemingly believes that the absence of a treaty-based arms control regime would only result in a large-scale arms race, thus it expressed its willingness to extend the New START. Moscow calls out the US disinterest in arms control as one of the challenges to stability and asserts that after abrogating the INF Treaty, Washington is "looking for an

\footnotetext{
${ }^{79}$ Hans M. Kristensen and Matt Korda, "Russian Nuclear Forces 2019," Bulletin of the Atomic Scientists 75, No.2 (2019): 73-84 (75), https://doi.org/10.1080/00963402.2019.1580891.

${ }^{80}$ Hans Kristensen and Matt Korda, "Russian Nuclear Forces, 2019," Bulletin of the Atomic Scientists, 75, No.2 (2019): 73-84 (75), https://doi.org/10.1080/00963402.2019.1580891 quoted in Amy F. Woolf, "Russia's Nuclear Weapons: Doctrine, Forces and Modernization," Congressional Research Services, January 15, 2020, https://fas.org/sgp/crs/nuke/R45861.pdf.

${ }^{81}$ Ibid., 6.

${ }^{82}$ Steven Pifer, The Future of U.S.-Russian Arms Control, (Carnegie Endowment for International Peace, 2016), 2, https://carnegieendowment.org/files/2-1716_Pifer_US_Russia_Arms_Control_clean.pdf.
} 


\section{Sufian Ullah}

excuse to get rid of New Start." ${ }^{183}$ For symbolic purposes, the arms control agreements also serve the Russian interests by placing it at equal standing with the US. On the issue of trilateral arms control negotiations, Moscow agrees with Washington to include Beijing in the multilateral arms control process. However, it asserts that US must show progress towards already agreed agenda items, like ratifying the CTBT, instead of proposing new initiatives like CEND.

\section{An Assessment of Chinese Approach towards Arms Control}

The Chinese leadership believes that arms control related efforts should aim to drawdown forces of US and Russia. China's nuclear policy is different from the other two nuclear armed states because it apparently does not call for parity and only focuses on enhancing the retaliatory capability. China neither faces imminent dangers of nuclear use against its Mainland nor does it believe that its arsenal poses any risks of escalation or inadvertent use of nuclear weapons. This is evident from its 'lean and effective' nuclear deterrent comprising of around 290 warheads and nuclear posture based on counter-value targeting and low-alert levels. ${ }^{84}$ Therefore, for China, arms control is not an essential tool to meet its policy objectives because these arrangements only aim to minimize the perceived dangers. However, in the absence of New START and any other treaty that could restrict the offensive use of conventional weapons, US counter-force capabilities both conventional and nuclear - may push China to develop more warheads and mobile ICBMs.

The Chinese experts believe that the traditional de facto mutual vulnerability in the relationship between China and US is eroding because of Washington's aspiration to develop first-strike capability against

\footnotetext{
${ }^{83}$ Russian Foreign Minister Sergey Lavrov's remarks at 2019 Moscow Non-Proliferation Conference. Quoted in Kingston Reif and Shannon Bugos, "U.S.-Russian Nuclear Arms Control Watch, Nov.15, 2019," Arms Control Association, November 15, 2019, https://www.armscontrol.org/blog/2019-11-15/us-russian-nuclear-arms-control-watch.

${ }^{84}$ Nuclear Threat Initiative, "China," accessed 06 July

2020, https://www.nti.org/learn/countries/china/.
} 


\section{Arms Control in Crisis: An Assessment of Contemporary Trends}

Beijing. ${ }^{85}$ China has long considered mutual vulnerability as the central pillar of Sino-US deterrent relationship, however, US does not equate this concept with the strategic stability. ${ }^{86}$ Likewise, US also does not prefer to describe Sino-US nuclear relationship as based on MAD. ${ }^{87}$ This disagreement on the baseline of nuclear deterrence between the two sides also has ramifications for arms race stability. The advanced emerging conventional weapons-like BMD, hypersonic missiles and so on-that US considers imperative for its security are seen by China as a serious threat to its nuclear second-strike capability. ${ }^{88}$ Just like the US-Russia bilateral dynamic, the Sino-US case is also witnessing the similar trend where China is developing precision strike weapons to match the technological advantage and counter Washington's missile defence systems. Due to a perceived threat of strike against its retaliatory forces, the improvements in Chinese nuclear arsenal are largely oriented towards improving survivability. ${ }^{89}$ China has conducted several tests of hyper glide vehicles, most recent being the test of DF-21 ballistic missile with a range of 2200 kilometer..$^{90}$

Beijing believes that the development of precision strike weapons may ensure a stable mutual deterrent relationship with Washington, which has already developed these systems and also enjoys overwhelming nuclear superiority over Beijing. ${ }^{91}$ Given the fact that reaching an agreement on

\footnotetext{
85 Tong Zhao, "What the United States Can Do to Stabilize Its Nuclear Relationship with China," Bulletin of the Atomic Scientists 75, No.1 (2019), 21, https://doi.org/10.1080/00963402.2019.1555992.

${ }^{86}$ Ibid.

${ }^{87}$ Caitlin Talmadge, "China and Nuclear Weapons," (paper, Brookings Institute, September 2019)https://www.brookings.edu/wpcontent/uploads/2019/09/FP_20190930_china_nucl ear_weapons_talmadge-1.pdf.

${ }^{88}$ Zhao, "What the United States Can Do to Stabilize Its Nuclear Relationship with China," 21.

${ }^{89}$ Talmadge, "China and Nuclear Weapons."

${ }^{90}$ Williams, "Asymmetric arms control and strategic stability: Scenarios for limiting hypersonic glide vehicles," 797.

${ }^{91}$ Zhao, "Conventional Challenges to Strategic Stability," 193.
} 


\section{Sufian Ullah}

how a wide range of conventional weapons may threaten the survivability of adversary's nuclear forces is difficult, the prospects of generating consensus on the need to explore new arms control measures also appear bleak. Only through continued strategic negotiations processes could the two sides develop common understanding on what stabilizes the deterrent relationship and how new technologies may embolden one side to launch an attack against the other.

\section{Prospects of Trilateral Arms Control Arrangement}

The proposal for a trilateral arms limitation agreement is unlikely to garner much interest in Beijing and thus holds little prospects for concrete steps towards this end. China believes that it is important for US and Russia to "reduce their nuclear weapons, both deployed and in stockpile, first so as to create conditions for other Nuclear-Weapon States to participate in nuclear arms reduction negotiations." 92 One of the Chinese diplomats is reported to have said: "Do you want to bring your arsenal down to our level (estimated at some 290 warheads), or our arsenal up to yours?"93 With a nuclear arsenal, less than one-tenth the size of America and Russia, there is little incentive for China to join any discussions on reducing its nuclear arsenal. It is also not clear that what kind of trilateral agreement the US wants to pursue? If it requires China to commit to the limitations already defined under New START, this would mean giving China legitimate option to increase its weapon stocks multi-fold. In the other scenario, would US and Russia be willing to reduce their own deployments to the level of China? Both the situations would not serve the American interest. For these reasons, several western experts like Thomas Countryman are of the

\footnotetext{
92 Ministry of Foreign Affairs of the People's Republic of China, "Remarks by H.E. Mr. Fu Cong, Director-General of the Department of Arms Control of the Ministry of Foreign Affairs of China on 'The Future of Arms Control and Non-Proliferation Regime' at the 2019 Moscow Non-Proliferation Conference," November 8, 2019, https://www.fmprc.gov.cn/mfa_eng/wjbxw/t1714403.shtml.

${ }^{93}$ Iain King, "The New Start Arms Control Treaty: Extend it, Go for More, or Let it Lapse?" Center for Strategic and International Studies, July 19, 2019, https://www.csis.org/analysis/new-start-arms-control-treaty-extend-it-go-more-or-let-itlapse-0.
} 
opinion that the proposal for trilateral arms control agreement is a pretext for withdrawing from or allowing New START to expire. ${ }^{94}$

Beijing expresses staunch opposition to US withdrawal from INF Treaty and the idea of making it a multilateral arrangement. ${ }^{95}$ The treaty prohibited Washington from deploying ground-based intermediate range missiles in Asia, allowing Beijing to retain a lean nuclear arsenal. ${ }^{96}$ The US withdrawal from the treaty and possible deployment of intermediate range missiles at the striking range from China further prevents the latter to not agree to prospective multilateral INF Treaty. Nevertheless, China emphasizes the need to regulate the military applications of emerging technologies. This supports the assertion that a state would consider arms control only in a domain where it feels itself vulnerable to adversary's capabilities.

Arms control is a product of fear and risky environment. Greater the risks of conflict escalation and eruption of war, greater will be the prospects of arms control. The emerging trends in arms control suggest that in the absence of consensus among competing states on how riskier the global environment is and how do the evolving military technologies threaten nuclear deterrence, the world is unlikely to see any new arms control arrangement. While in the absence of New START, there are concerns about nuclear opacity and unconstrained development of strategic forces, but these concerns are not yet seen as significant threats by major powers. On the other hand, U.S. is more concerned about its leadership role in the non-proliferation regime that is questioned by the non-nuclear NPT States in the form of new Treaty on the Prohibition of Nuclear Weapons. While

\footnotetext{
94 Thomas Countryman, "Russia, China, Arms Control, and the Value of New Start," Arms Control Association, accessed on July 07, 2020, https://www.armscontrol.org/act/201911/features/russia-china-arms-control-value-new-start.

95 Ministry of Foreign Affairs of the People's Republic of China, "Foreign Ministry Spokesperson Geng Shuang's Remarks on the US Suspending INF Treaty Obligations and Beginning Withdrawal Process," February 02, 2019, https://www.fmprc.gov.cn/mfa_eng/xwfw_665399/s2510_665401/2535_665405/t16352 68.shtml.

96 Andrey Baklitskiy, "What the End of the INF Treaty Means for China," Carnegie Moscow Center, December 02, 2019, https://carnegie.ru/commentary/80462.
} 


\section{Sufian Ullah}

the INF Treaty and New START were the only verifiable tools to show progress towards Article VI of the NPT, US has now proposed CEND as a new measure to appease those States and address their resentment. However, this initiative is not only unrealistic but also an escape from already agreed NPT benchmarks. CEND seems to be a response to renewed emphasis by non-nuclear NPT states on prohibiting nuclear weapons. More focus on CEND in coming times may divert focus from issues like progress on proposed Fissile Material Cut-off Treaty.

In the context of major powers' growing reluctance to enter into arms control arrangements and evolution of new conventional technologies that may have strategic implications, competing states may utilize the time to develop adequate capabilities. The leading powers in the domain of technological developments may introduce new arms control initiatives once the ongoing research and development in the fields like cyber and artificial intelligence is incorporated into the military domain. Thus, "negotiations should be delayed until, like ancient Athens, [the] fortifications had been rebuilt." ${ }^{97}$ For symbolic and political advantages, however, the world may witness repeated emphasis on multilateral approaches to promote restraint, but any concrete progress on addressing the root causes appears unlikely. The earlier discussion on how states reluctantly enter into arms control agreements, remain elusive about the utility of these measures, and continue modernizing their forces to deny the adversary of achieving a monopolistic position suggests that arms control may have a limited utility but it, at minimum, offers short-term measures to manage crises. These measures ideally may not be tantamount to more preferable approaches of conflict resolution, but it promises the prospects of discouraging adversaries from engaging in warfare and control the escalation processes, if war breaks out. Thus, the arms race stability directly contributes to bolster crisis stability. However, for adversarial states to reach such an agreement requires consensus on the mutually shared threats and how certain technologies implicate the stability. As long as a certain state believes that it is invulnerable to prevailing or emerging threats, it may

\footnotetext{
${ }^{97}$ Nye Jr, “Arms Control and International Politics.” 146.
} 
not be willing to enter into any arms control negotiations. Thus, adversary's offensive capabilities - rather than relatively larger arsenal-that directly threaten one state's security would shape latter's arms control preferences.

\section{Conclusion}

The emerging technologies, rather than normative political emphasis on restraint, are likely to lead the future of arms control. The role of arms control in major military powers' strategic policy-making choices would depend on these technologies and their applications. The mismatched perceptions and fears about each other's intentions fuels competition. Unless these states develop consensus on how evolving technologies challenge the mutual security, it is unlikely that arms control would figure prominently in their strategic and foreign policy choices. Strategic negotiations are key to develop common understanding about evolving dynamics of deterrence, changing requirements for strengthening mutual vulnerability, and how to prevent escalation of conflicts involving intermingled nuclear and conventional weapons. The concrete progress on arms control requires major powers like the US, Russia and China to reconcile their arms control agendas.

There is a need to find a common framework for maintaining nuclear stability, and the plausible start towards this end could be initiating dialogues on identifying the shared risks and possible ways to reduce the dangers. The assessments based on worst-case scenario analyses about each other's military capabilities would only prove misleading. ${ }^{98}$ Instead of resorting to unabated competition, the prevailing and emerging challenges to global peace and security require a return to comprehensive arms control mechanisms that not only address the numbers but also possible dangerous applications of evolving weapons. However, in the wake of increasing multipolarity, reaching consensus on such an approach appears highly unlikely.

98 Zhao, "What the United States Can Do to Stabilize Its Nuclear Relationship with China," 